\title{
O multiculturalismo e a dialética do universal e do particular
}

CELSO FREDERICO ${ }^{I}$ Omo deveriam conviver as diversas culturas no Estado democrático de di-
reito?

Há, pelo menos, duas respostas possíveis.

A primeira enfatiza as diferenças culturais e étnicas para, em seguida, propor a "luta pelo reconhecimento" de tais diferenças como forma de compensar as desigualdades e viabilizar uma integração social que preserve as diferenças. Essa resposta é orientada por uma lógica cultural.

A segunda, contrariamente, desloca a ênfase da cultura para a esfera socioeconômica. Por isso, reivindica uma política pública que favoreça a integração no mercado de trabalho como condição para a realização da cidadania e dos valores comuns à sociedade. Objetiva, dessa forma, evitar que as diferenças culturais se enrijeçam e ponham em perigo a democracia.

Cada resposta acena para caminhos diferentes: ou se considera a nação como um conjunto de etnias diferenciadas ou se aposta numa visão assimilacionista que valoriza o hibridismo como constitutivo da nacionalidade e da cidadania.

Atualiza-se, assim, no campo político, a oposição entre os direitos particularistas (das chamadas "minorias"), defendidos pelos diversos movimentos sociais e os direitos universais do cidadão, estabelecidos com a Revolução Francesa de 1789.

Argumentos fortes são utilizados nessa contenda pelas duas correntes.

Os defensores do particularismo têm razão quando denunciam o caráter abstrato de um universalismo centrado na ideia falsa de cidadania que proclama que todos os homens são iguais perante a lei embora sejam desiguais na vida real. O universalismo é chamado pelos militantes do multiculturalismo nos Estados Unidos pela sigla Wasp (White, Anglo-Saxon and Protestant).

Os defensores do universalismo, por sua vez, têm razão ao criticar a ênfase exagerada nos interesses particularistas, afirmando que eles impedem a convivência democrática e o entendimento entre os homens.

Estamos, portanto, diante de um confronto que perpassa o campo da cultura, da política e da filosofia.

\section{Multiculturalismo e luta pelo reconhecimento}

A luta pelo reconhecimento, antes de ser levantada pelo multiculturalismo, teve suas origens na França, quando um movimento político, a guerra pela 
libertação da Argélia (1954-1962), repercutiu fortemente na então hegemônica filosofia existencialista.

A guerra anticolonialista da Argélia trouxe para o universo intelectual existencialista as ideias de Albert Memmi e Franz Fanon. Paralelamente, os pensadores ligados ao existencialismo assistiam aos cursos de Alexandre Kojève, dedicados à filosofia de Hegel (cf. Descombes, 1998). Um dos temas que mais entusiasmo despertaram foi a dialética do senhor e do escravo, presente na $\mathrm{Fe}$ nomenologia do espirito. Essas duas figuras da consciência empenhavam-se numa luta pelo reconhecimento. Com esse referencial abstrato, a reflexão filosófica encontrou-se com a ação política.

Os escritos sobre o colonialismo de Albert Memmi (1985) e Franz Fanon (2010) tiveram forte impacto na intelectualidade francesa que protestava conta a guerra da Argélia. Fanon, por exemplo, afirmava enfaticamente que a principal arma utilizada pelos franceses era a imposição de uma imagem aos povos colonizados - uma imagem evidentemente negativa e depreciativa do colonizado que, uma vez internalizada por ele, bloqueava as possibilidades da luta pela emancipação. A primeira tarefa, portanto, deveria ser a luta para modificar essa imagem, uma luta pela autoconsciência e pelo reconhecimento. ${ }^{1}$

Nesse ambiente cultural e político, Sartre (1971, p.181), de modo semelhante, observou que "o escravo vê-se com os olhos do senhor. Pensa-se a si próprio como um Outro e com os pensamentos do Outro". O olhar surgia assim como tema central da filosofia existencialista às voltas com a dialética do reconhecimento. Através do olhar do outro a reificação se efetiva: ser olhado nos transforma em objeto. ${ }^{2}$

A companheira de Sartre, Simone de Beauvoir (1960), foi pioneira no estudo da condição feminina com a publicação do livro O segundo sexo. Uma de suas fontes é, também, a dialética do senhor e do escravo de Hegel. Educada desde sempre para cumprir determinados papéis fixados pela sociedade patriarcal, a mulher internaliza tais papéis e vive para representá-los, perdendo a sua autodeterminação e transformando-se num ser-para-outro que procura, mecanicamente, corresponder à imagem que o homem espera dela. Mas, agindo assim, ela aliena a sua identidade ao se transformar na caricatura do que ela imagina que o Outro espera dela ou, nas palavras da autora, se transforma no Outro do Outro. $^{3}$

O movimento feminista surgiu para lutar contra a alienação da mulher, luta que se inicia na crítica aos papéis sociais que lhe são impostos e no reconhecimento da igualdade entre os sexos.

A partir daí generalizaram-se os movimentos sociais voltados a reverter a imagem de inferioridade. A luta pelo reconhecimento consolidou, inicialmente, os direitos civis: as mulheres obtiveram o direito de voto e os negros, as leis antirracistas. O Estado democrático, assim, passou a implementar a política do universalismo, consagrando a igualdade de todos os cidadãos. 
Num segundo momento, a luta pelo reconhecimento sofreu uma transformação: o reconhecimento da igualdade cedeu lugar à luta pelo reconhecimento das diferenças. Nesse momento, o Estado democrático enfrenta um novo desafio: dar conta da reivindicação particularista de sujeitos coletivos, numa ordenação jurídica que faz do indivíduo isolado o portador de direitos universais.

\section{Liberais e comunitaristas}

O texto clássico e referência incontornável sobre a política do reconhecimento foi escrito por Charles Taylor (2009), ${ }^{4}$ a partir de suas reflexões sobre o debate multiculturalista no Canadá.

Como se sabe, Québec se constituiu num Estado dentro do Estado canadense e lutou para manter a língua e a cultura francesas. Para isso, foi instituída constitucionalmente a questão da preservação dessa cultura. Os filhos de pais que falam francês são obrigados a frequentar escolas onde só se fala francês. Paralelamente, outras minorias culturais também se empenharam na defesa de suas culturas: os aborígines e os imigrantes, sem falar nas mulheres, que, ao fim e ao cabo, não são minorias.

Entrava em cena, assim, o debate sobre as políticas públicas e o direito à diferença das minorias que passam a reivindicar a política do reconhecimento, que abarca, segundo Taylor, desde profundas necessidades psicológicas dos indivíduos até comunidades inteiras, já que nossa identidade é formada pelo reconhecimento ou pela sua falta e, também, pelo falso reconhecimento que nos é imposto pelos outros.

Taylor lembra que esse é um problema próprio dos regimes democráticos. No mundo feudal, ao contrário, vigorava a desigualdade expressa na honra, um princípio de distinção próprio da nobreza e, portanto, não extensivo à plebe. Com o fim da ordem estamental, consagra-se o princípio da igualdade jurídica entre os cidadãos como imperativo para preservar a "dignidade humana". Em tempos recentes, marcados pelo multiculturalismo, começa-se a reivindicar a igualdade de status para as "minorias" descontentes com a existência de uma igualdade formal que mal consegue disfarçar as desigualdades reais existentes e a humilhante situação opressiva a que foram relegadas. Passamos, assim, da reivindicação da igualdade para o reconhecimento das diferenças.

As relações entre a política de identidade e o direito são complexas e, por isso, vêm propiciando debates acalorados. O texto de Charles Taylor confronta duas posições típicas do liberalismo.

A primeira delas, o Liberalismo 1 , afirma o universalismo do direito, ou seja, insiste na aplicação uniforme do direito e, portanto, não tolera a diferença. Perante as diversas culturas mantém uma posição de indiferença.

O Liberalismo 2, ao contrário, não é indiferente às culturas e empenha-se

na sua preservação. É, portanto, um "credo combatente" que inclui a diversidade nas políticas estatais conservacionistas. Taylor insere-se nessa corrente. 
Os defensores dessas duas posições ficaram conhecidos, respectivamente, como liberais e comunitaristas. Podemos notar ao menos dois pontos de divergência entre eles: as relações do indivíduo com a cultura a que pertencem e a posição que o Estado deveria ter perante a diversidade cultural.

Os liberais priorizam as escolbas do individuo e não o contexto cultural em que ele está inserido. Para eles, a existência de diferentes culturas com seus respectivos valores é vista com indiferença. O privilégio do indivíduo e de suas escolhas pressupõe uma visão atomista da sociedade, que não se impõe ao indivíduo, que não determina nem condiciona suas escolhas. Trata-se, pois, de uma concepção individualista que considera o indivíduo uma mônada autossuficiente que se orienta racionalmente em suas escolhas, livre de qualquer determinação social.

Os comunitaristas, ao contrário, conferem prioridade aos laços comunitários que envolvem os indivíduos e dentro dos quais eles se movimentam e formatam suas identidades. Os indivíduos são seres sociais inseridos em contextos culturais, e é no interior dos grupos de pertença que eles se desenvolvem. Há, assim, uma prioridade ontológica do grupo cultural: os indivíduos são seres sociais, membros de uma coletividade que baliza suas escolhas. Não haveria, portanto, nem a plena autonomia dos indivíduos, nem a neutralidade perante a diversidade cultural como querem os liberais. A cultura, para os comunitaristas, é um valor e, como tal, precisa ser conservado, é um valor concernente à comunidade e essa não se resume ao somatório de indivíduos.

O segundo ponto a separar os contendores diz respeito a quem caberia a proteção das diferenças. Os liberais, quase sempre, se inclinam para as instituições da sociedade civil; já os comunitaristas veem o Estado como o órgão capaz de implementar políticas públicas visando o reconhecimento e a proteção das diferenças dos grupos minoritários. Portanto: enquanto os liberais defendem a ideia do Estado como uma agência neutra e reafirmam a igualdade jurídica entre os indivíduos, os comunitaristas põem em dúvida a neutralidade estatal, para eles prisioneira de uma cultura dominante e, pela mesma razão, desconfiam da pretendida igualdade dos indivíduos. Por isso, recusam o universalismo abstrato dos liberais em nome de políticas públicas compensatórias sensíveis às reivindicações de reconhecimento para os diversos grupos culturais.

A polêmica entre essas duas correntes propiciou uma extensa bibliografia. Na sequência, alguns autores como Jürgen Habermas, Axel Honneth etc. entraram no debate buscando uma superação daquelas posições. Não cabe aqui discutirmos esses autores que partem de outros contextos teóricos, densos e complexos, o que nos afastaria de nossos objetivos. ${ }^{5}$ Mas uma questão deve ser lembrada: a equiparação proposta por Taylor entre preservação das espécies e preservação das culturas. Segundo Habermas (2002, p.250-2), tal equiparação não faz sentido. A preservação da cultura garantida pela lei aproxima-se do fundamentalismo e de sua tentativa de restaurar uma "substancialidade já decaída" numa sociedade moderna em transformação que "manda pelos ares todas as for- 
mas estacionárias de vida". As culturas só sobrevivem graças à autotransformação que pressupõe a liberdade dos indivíduos de se posicionarem criticamente perante a herança cultural.

\section{Cultura e política}

A discussão sobre o multiculturalismo repõe a oposição entre universal e particular referida não mais às categorias da lógica, mas para dar conta do embate entre os direitos universais consagrados pela Revolução Francesa e as reivindicações particularistas dos movimentos sociais que pleiteiam o reconhecimento de suas especificidades.

Rouanet nomeia a primeira posição de "igualitarismo abstrato", pois abole as particularidades, e, a segunda, de “diferencialismo abstrato”, para o qual só a diferença, considerada um valor em si mesma, existe (cf. Rouanet, 2009).

A crítica ao "igualitarismo abstrato" tem razões para existir. Tal crítica, entretanto, conduziu o multiculturalismo a uma visão estática e essencialista de cultura e a um relativismo exacerbado que trouxe consequências problemáticas à ação política.

O relativismo, que acompanha as diferentes versões do multiculturalismo, propiciou intensos debates políticos. E não poderia ser de outro modo, pois a cultura é o campo minado em que a alteridade se exaspera em oposição e contradição.

Certa feita, li no jornal a declaração de um industrial durante a inauguração do centro cultural Norberto Bobbio, da Federação das Indústrias do Estado de São Paulo (Fiesp): “a política divide, a cultura unifica”. A cultura, assim, é entendida erroneamente como uma esfera neutra acima das contradições sociais.

Antes de chegar ao discurso do industrial, essa concepção elitista fez-se presente em diferentes contextos históricos. Na Inglaterra, por exemplo, ela surgiu com o advento da sociedade industrial capitalista e da democracia: de repente, a cultura até então usufruída por um seleto público passou a sofrer as consequências da complexidade do tecido social e do surgimento das camadas populares que passaram a ameaçar o consenso cultural vigente. Para autores como Matthew Arnold, T. S. Eliot e F. R. Leavis, tratava-se primordialmente de preservar os valores elevados da cultura. ${ }^{6}$ No Brasil, como em outros países da América Latina em certo momento, à literatura foi atribuída outra função: colaborar com a formação da identidade nacional. Em nome desta, as diferenças culturais foram apagadas: no romantismo, o índio é "integrado" pela visão mítica como símbolo da brasilidade; o naturalismo, ao contrário, irá naturalizar o negro, relegado à pura animalidade, de forma que sua incômoda presença não emitisse um julgamento sobre o mundo da escravidão. Em todos os casos, lá como aqui, a literatura permanece flutuando acima da vida social, cumprindo uma missão integradora.

Fredric Jameson (1994, p.29), contrariamente, assinalou o caráter necessariamente conflitivo da cultura, dada a inserção nas contraditórias relações sociais: 
Pois a cultura - a versão mais fraca e secular daquilo que se chama religião - não é em si uma "substância" ou fenômeno, é uma miragem objetiva que surge do relacionamento entre pelo menos dois grupos. Isto significa que nenhum grupo "possui" uma cultura sozinha: a cultura é o nimbo percebido por um grupo quando entra em contato com e observa outro grupo.

Essa característica básica, válida tanto para os povos "exóticos” como para as culturas urbanas marginalizadas, só pode ser superada e conservada quando ascendemos para o campo da política. Essa passagem à política tem, também, uma longa história que remonta à formação do Estado-Nação. Segundo o denso estudo de Habermas, foi graças ao surgimento do Estado-Nação na Europa que a ideia de uma comunidade unida pôde se afirmar e com ela a cidadania democrática. Desse modo priorizou-se "um entendimento cosmopolita de nação como uma nação de cidadãos, em detrimento de uma interpretação etnocêntrica da nação como uma entidade pré-política”. As “esgarçadas formas tradicionais de integração social” foram, então, substituídas “pela força integrativa da cidadania democrática”. Tal substituição, contudo, observa Habermas (1995, p.94), não eliminou a "tensão entre o universalismo de uma comunidade legal igualitária e o particularismo de uma comunidade cultural a que se pertence por origem e destino".

Nos tempos atuais, aquela tensão vem se exasperando continuamente. A antiga população mais ou menos homogênea em termos culturais cedeu lugar às atuais sociedades pluralistas, incapazes de apaziguar as diferenças. As tensões sociais, impulsionadas pela pobreza e pela marginalidade, criaram uma situação explosiva. Nas palavras de Habermas (1995, p.100):

o veneno dos guetos dissemina-se pela infraestrutura das cidades e das regiões, permeando os poros de toda a sociedade [...] a segregação das minorias, que se veem privadas de voz reconhecida na esfera pública, traz consigo uma erosão da moralidade, algo que com certeza mina a força integrativa da cidadania democrática. Decisões formalmente corretas, que refletem o anseio de status de classes médias ameaçadas, terminarão por minar a legitimidade dos procedimentos e instituições do Estado constitucional.?

Nesse contexto conturbado, a luta pelo reconhecimento acabou politizando a cultura e a etnicidade. Um estudioso francês, Michel Cahen, debatendo no Brasil com integrantes do Movimento Negro Unificado, estranhou o fato de eles falarem em relações "étnico-raciais” e lançou a pergunta: "isso quer dizer que os negros são uma etnia e os brancos, outra etnia? [...] será que os negros são uma raça e os brancos uma outra raça?". Diante da resposta negativa, insistiu: "se não há raças, nem etnias, por que vocês falam sempre em relações étnico-raciais?”. Ouviu como resposta: "é mais eficaz politicamente" (Cahen, 214, p.19).

A politização das diferenças (no caso: etnias) demonstra que a cultura agora mantém uma estranha relação com a política.

A luta pelo reconhecimento exige, antes de tudo, uma clara delimitação dos grupos culturais que devem ser reconhecidos, uma definição prévia de sua 
substância. Quais os grupos que “merecem” ser reconhecidos? Qual o critério para enquadrá-los nas políticas sociais?

Surge aqui uma questão complicada. Diversos antropólogos se debruçaram sobre o processo que propiciou a diferenciação étnica dos Xocó e dos Mocambo numa comunidade rural em Sergipe que, até então, se sentiam ameaçados na disputa pela posse da terra com os latifundiários. Durante décadas, esses dois grupos viviam juntos, mantendo relações de cooperação e parentesco. Nos anos 1990, eles se separaram. Os Xocó passaram a se "reconhecer" como índios (embora tivessem a pele negra, eram católicos e falavam somente o português). Os Mocambo, por sua vez, reivindicaram a ascendência quilombola. Os primeiros, ao escolherem serem índios, ganharam a proteção da Fundação Nacional do Índio (Funai); já os Mocambo, "convertidos" à negritude, ficaram sob a guarda do Instituto Nacional de Reforma Agrária (Incra). Apesar da separação, continuaram a compartilhar formas de vida semelhantes.

Paula Montero (2012), comentando a divisão, observou que a etnicidade tornou-se aí "uma categoria construída para fins de obtenção de direitos específicos”, graças à ação externa de agentes mediadores:

Padres católicos e antropólogos coligiram memórias, organizaram relatos, produziram provas e convenceram os "nativos" da necessidade de se autoidentificarem, e advogados colaboraram na formatação da causa jurídica percebendo a oportunidade que a Constituição oferecia de deslocar o pleito do campo do reconhecimento da posse (direito dos posseiros) para o reconhecimento da tradição. (Montero, 2012, p.85-9)

Desse episódio, ela tirou diversas conclusões. Entre outras: a “juridicização" do processo de produção das identidades; a transformação desse processo num mecanismo destinado a promover uma justiça distributiva "não mais apoiada no paradigma da desigualdade de classes"; a migração do fenômeno da identidade do campo da cultura para o campo da política; a dúvida em saber até que ponto esse processo, apoiado na "ficção da autenticidade da cultura" afeta ou não "o modelo de coesão nacional clássico baseado, no caso brasileiro, no imaginário da mestiçagem e da assimilação" ao transformar a ideologia do "mulatismo", do hibridismo, na crença de uma nação formada por "heranças paralelas e pluriétnicas" (ibidem).

A afirmação da diferença não se limitou ao caso narrado. Interessa lembrar aqui seus reflexos no campo cultural. O multiculturalismo insiste em afirmar que todas as culturas são igualmente importantes e têm algo a dizer para todos nós - e, por isso, devem ser preservadas. Não por acaso, essa concepção é contemporânea do movimento ecológico e sua crença no caráter sagrado de todas as formas de vida. Nesse contexto, porém, surgiu também a indústria da etnicidade: as guerras jurídicas visando a comercialização do patrimônio cultural. Assim, a lógica mercantil, que gere o funcionamento da sociedade global, impõe-se às chamadas minorias, colonizando-as (cf. Magagno, 2014, p.200). 
Resta ainda um comentário sobre educação. A luta pelo reconhecimento, como era de esperar, chocou-se com o eurocentrismo que orienta os currículos escolares. Paralelamente às ações afirmativas no campo educacional (ProUni, cotas etc.), instituiu-se a disciplina "História e Cultura Afro-Brasileira e Africana" nos ensinos fundamental e médio. A crítica ao eurocentrismo e o resgate da cultura africana e de sua enorme importância para a formação da nacionalidade são iniciativas corretas e necessárias.

Mas é sempre bom precaver-se contra a possibilidade de culturalizar a vida social, já que agora o reconhecimento diz respeito não aos direitos das chamadas minorias, e sim à preservação de um longínquo legado cultural. Cito, a propósito, um exemplo. Recentemente, surgiu uma proposta no Ministério da Educação para a reestruturação dos currículos escolares dos ensinos fundamental e médio (Brasil, s. d., p.235-65). O que se depreende da leitura desse longo documento, sem muita dificuldade, é a tentativa de substituir a história universal pelas histórias fragmentadas, tendo como centro a valorização das culturas relegadas ao esquecimento (africana, indígena) e de seus protagonistas ("sujeitos"). A base material da sociedade cedeu então lugar às tradições culturais; os ciclos econômicos que marcaram o desenrolar de nossa história (açúcar, café, borracha etc.) foram substituídos pelo estudo antropologizante do legado cultural.

O currículo de História, com ênfase na História do Brasil, passou a gravitar em torno de um "enfoque predominante" traduzido nos títulos a seguir arrolados.

Ensino fundamental

$1^{\circ}$ ano - Sujeitos e Grupos sociais.

$2^{\circ}$ ano - Grupos sociais e comunidades.

$3^{\circ}$ ano - Comunidades e outros lugares de vivências.

$4^{\circ}$ ano - Lugares de vivências e relações sociais.

$5^{\circ}$ ano - Mundos brasileiros.

$6^{\circ}$ ano - Representações, sentidos e significados do tempo histórico.

$7^{\circ}$ ano - Processos e Sujeitos.

$8^{\circ}$ ano - Análise de processos históricos.

$9^{\circ}$ ano - Análise de processos históricos.

Ensino médio

$1^{\circ}$ ano - Mundos ameríndios, africanos e afro-brasileiros.

$2^{\circ}$ ano - Mundos americanos.

$3^{\circ}$ ano - Mundos europeus e asiáticos.

Essa pitoresca forma de se ensinar História revela bem a confusão presente no universo multiculturalista. Somente no último ano entram em cena os "mun- 
dos europeus". Mas, como entender o colonialismo e a escravidão sem falar no capitalismo comercial? A desistorização do ensino da História tem como resultados uma completa desmaterialização do real, uma autonomização da cultura, uma idealização dos "lugares de vivência" e dos pretensos sujeitos com seus "saberes" e "fazeres".

\section{De volta ao universal}

No plano teórico, que ora duplica o que se passa nos movimentos sociais e ora fornece subsídios aos militantes do muticulturalismo, subjaz uma concepção de mundo que recusa o universal em nome das "micronarrativas" - a história dos negros, das mulheres, dos gays etc. A proximidade com o pós-modernismo, no que diz respeito à crítica dos "grandes relatos", torna inviável a existência de uma história universal por todos compartilhada. Alguns autores usam a expressão "guetos cognitivos" ou "apartheid progressista" para caracterizar criticamente a proposta; outros apontam a proximidade ideológica com o liberalismo ${ }^{8}$ e a visão de uma sociedade democrática em que as diferenças se acomodam cada qual em seu canto. Zizek (2008), por sua vez, fala em "racismo invertido" ao apontar para o "perigoso slogan": iguais, porém separados, o que lhe parece o "ideário do apartheid".

O confronto entre o culturalismo e o ideal democrático ressurgiu na França há alguns anos. $\mathrm{O}$ eixo do debate era o uso de símbolos religiosos (especificamente, a burca) nas escolas públicas e laicas. Após vários anos de discussão acalorada, o governo francês decretou a proibição. Não faltaram bons argumentos dos dois lados: a crítica à intolerância estatal que fecha os olhos para as demais culturas e persegue os muçulmanos: fala em universalismo, mas está a serviço de um particular; ou, na outra ponta, a defesa da laicidade ameaçada pelo fundamentalismo - uma identidade fanática que quer impor o seu particularismo a todos.

De novo, a dialética entre o universal e o particular reaparece. Cito a propósito mais um exemplo a que assisti. Numa cidade do litoral paulista, um grupo de vizinhos discutia o acontecido: um pedreiro, que prestava serviço a todos, havia sido acusado de ter estuprado um rapaz deficiente mental. Estavam todos indignados. Então, uma assistente social interferiu: "precisamos entender que ele é caiçara e que, na cultura dele, isso não é tão grave".

É evidente que se deve respeitar a diversidade cultural e sua convivência pacífica dentro do Estado democrático, mas isso pressupõe uma cultura política comum que deve ser aceita. As diversas culturas não vivem isoladas, mas em contato e, acima de todas elas, estão as regras de convivência sancionada pelo direito. Por isso, o estupro, por menos "grave" que possa ser considerado na cultura caiçara, não pode ser tolerado. Igualmente, não é aceitável, em nome da diversidade cultural, o apedrejamento das mulheres adúlteras.

Foi por essas razões que o governo francês proibiu o uso do véu islâmico nas escolas públicas. A proibição se baseia no princípio de que os imigrantes de- 
vem aceitar a laicidade do Estado: quem emigrou para a França fez uma escolha e, portanto, deve compartilhar as regras da convivência existentes daquele país.

A luta pelo reconhecimento, como todo confronto de dimensões políticas, teve como um de seus funestos e imprevistos resultados uma odiosa reação, também ela apoiada numa visão essencialista e particularista: a xenofobia ressurgiu violentamente para defender a "pureza" racial (e a defesa dos empregos), através da "limpeza étnica". Desse modo, o "diferencialismo abstrato", de um lado, gerou a segregação e, de outro, o ódio racial. Nos Estados Unidos, o ataque às torres gêmeas em 2001 avivou o extremismo islâmico e a intolerância racista contra os estrangeiros. Angela Merkel, um ano antes, havia anunciado: “o multiculturalismo fracassou".

É hora, portanto, de revermos a crítica ao universal, o ponto de partida do multiculturalismo.

A denúncia do "universalismo abstrato" e sua concepção, segundo a qual, "lei é igual para todos" constata, com razão, que ele iguala os desiguais e impõe uma pretensa uniformidade. Tal concepção remonta ao Iluminismo, que, concebendo os homens, genericamente, como seres racionais, não atentava para as diferenças individuais. Contra esse nivelamento, o romantismo se opôs, exaltando a singularidade e colocando-a em oposição ao universal.

A dialética surgiu para superar essa antinomia. Hegel afirmava que não existe um abismo intransponível entre o universal e o singular e nem uma relação de exterioridade, já que os singulares são partes constitutivas do universal e este se encarna nos seres singulares (basta lembrar "o homem universal" do Renascimento e os "personagens típicos", do romance realista). Não se pode, portanto, confundir a concepção dialética de "universal concreto" com a visão niveladora do "universal abstrato".

Segundo Hegel, esta última deve ser entendida como manifestação inicial, imediata, do conceito de universal, ainda abstrato, vazio, indeterminado. Por isso, Hegel introduziu em seu conceito dialético as sucessivas determinações que enriquecem o universal e que são seus momentos constituintes. Desse modo, as particularidades podem, enfim, se reconhecer, integrando-se harmonicamente no universal e tornando-se conscientemente partes dele sem perder, entretanto, suas qualidades específicas. O universal, para a dialética, não é uma noite em que todos os gatos são pardos e nem implica o cancelamento das qualidades inerentes dos singulares, que, despojados daquelas, seriam integrados à força numa pretensa indiferenciada unidade. A dissolução dos diversos na monotonia do Uno é acusação antiga levantada pelos críticos do hegelianismo. Marx saiu em defesa de Hegel, afirmando que o primado do geral sobre os particulares não significava a diluição destes "under a general principle".

Tal diluição está presente hoje na falsa universalidade da chamada globalização. De um lado, ela colocou em crise o Estado-Nação, aquela instituição que, segundo Habermas, possibilitou a afirmação da política como a estrada que 
pavimentaria o acesso ao verdadeiro universal. De outro, ela impôs em seu lugar um pretenso universal: a sociedade de consumo. Agora, sim, pode-se falar em homogeneização pasteurizadora num mundo povoado pelas falsas equivalências: as diferentes mercadorias, esvaziadas de seu valor de uso, equiparadas pelo abstrato valor de troca; os indivíduos pertencentes às diferentes classes sociais nomeados indistintamente como "cidadãos"; e, finalmente, estes últimos transformados em "reivindicantes" consumidores que lutam em aparente igualdade de condições pelos seus "direitos" num mercado que, cinicamente, consagra a "soberania do consumidor".

Esse brutal contraste entre o universalismo do mercado e a fragmentação das identidades presente no multiculturalismo tem levado diversos autores a buscar um nexo entre esses dois fenômenos. Zizek, por exemplo, recorre à psicanalise de Lacan para ver no multiculturalismo um sintoma do capitalismo contemporâneo. Na mesma linha, o psicanalista Conrado Ramos constatou: "o multiculturalismo passa a ser um sintoma das políticas pós-modernas e neoliberais que fragmentam a sociedade de consumo multiplicando targets massificados cuja adesão cumpre à propaganda convocar, em nome das diferenças". Assim, "a democracia, a tolerância, a correção política, o respeito e a igualdade de direitos sustentados pelo multiculturalismo só são possíveis de fato dentro das relações abstratas e universalizantes do mercado" (Ramos, 2009, p.50 e 54).

Fora das relações de mercado, contudo, concentra-se a massa de indivíduos privados, não de subjetividades desejantes, mas de empregos estáveis. Dentro do mercado coexistem as diferentes classes sociais que se debatem, não pelo reconhecimento de suas diferenças, mas pela posse da riqueza produzida pelo trabalho social. O multiculturalismo, contrariamente, substituiu a contradição pela diversidade.

Se o campo da cultura, como disse Habermas, é pré-político e, historicamente, só produziu as "as esgarçadas formas tradicionais de integração social", é preciso então resgatar a dimensão da política, da democracia, do ideário republicano, da emancipação social, pois é aí que o universal pode progressivamente se realizar. Por isso, alguns autores, voltando à concepção dialética, preferem falar em "universalismo concreto" para dar conta de um processo através do qual a lei poderá produzir a igualdade para todos. Só assim é possível sair da "pequena política", da fragmentação cultural dos particulares que não se entendem, para a "grande política": a luta contra a exploração econômica, fonte primária da desigualdade e dos conflitos contra as formas de descriminação social das diferenças.

\section{Brasil: o multiculturalismo como política pública}

O multiculturalismo como política pública implementada pelo Estado fez o seu ingresso entre nós no seminário sobre multiculturalismo e racismo, realizado em 2 de junho de 1996, durante o governo Fernando Henrique Cardoso. Para o seminário, organizado pelo Ministério da Justiça, foram convocados em Brasília diversos intelectuais brasileiros e brasilianistas norte-americanos para 
discutirem a introdução das affirmative actions, no país. A centralidade da questão racial, como era de esperar, sugeria obviamente uma comparação entre Brasil e Estados Unidos. ${ }^{9}$

Monica Grin (21, p.173), em seu ensaio dedicado ao seminário, chama a atenção para uma questão de fundo que nos alerta para a simples cópia da experiência norte-americana perguntando:

se há na ordem social brasileira os "sujeitos raciais" de direito para os quais deveriam ser dirigidas aquelas políticas. Assim, a pergunta que o debate de Brasília se colocava de forma mais incisiva era: qual o estatuto ontológico da "raça" no Brasil? Existem sujeitos "raciais"? Ou seja: os sujeitos sociais se definem e se percebem a partir de uma clara divisão racial?

Afirmar que, à semelhança dos Estados Unidos, haveria entre nós “sujeitos raciais", como pretendiam alguns dos intelectuais presentes, bem como algumas correntes do movimento negro, tem como resultado a politização das diferenças e uma concepção racializada da vida social. Trata-se aqui da transposição de uma problemática norte-americana da race-conscious - a tomada de consciência da negritude como pressuposto para a luta por políticas compensatórias que visem à diminuição das desigualdades. Mas no Brasil, contrariamente, a tomada de consciência surge como um resultado da ação estatal que pretende criar os "sujeitos sociais" a serem incluídos através das intervenções focais compensatórias (as targets, como se diz na língua inglesa).

Contra essa importação de uma problemática de um país que nada tem a ensinar para ninguém sobre a questão racial, o seminário contou com a lucidez de Fabio Wanderley Reis (1996, p.222):

[...] qual é a sociedade que almejamos no que se refere às relações raciais? A resposta, a meu juízo é clara: queremos uma sociedade em que as características raciais das pessoas venham a mostrar-se socialmente irrelevantes, isto é, em que as oportunidades de todo tipo que se oferecem aos indivíduos não estejam condicionadas por sua inclusão neste ou naquele grupo racial. Se prestamos atenção ao significado original do termo "discriminação", usado como algo condenável quando se trata de raças, vemos que ele se refere justamente ao fato de que os traços raciais sejam ou não percebidos ou tomados como relevantes: queremos uma sociedade que não "discrimine" ou "perceba" as raças, isto é, que seja no limite, cega para as características raciais dos seus membros.

A criação dos "sujeitos raciais", no Brasil, esbarra na especificidade de um contexto que nada tem a ver com os Estados Unidos. A "gradação" entre as "raças" estabelece um continuum que borra a rígida diferenciação entre brancos e negros existentes nos Estados Unidos, expressa na antiga lei do one-drop rule segundo a qual uma única gota de sangue negro herdada dos ancestrais é suficiente para classificar o indivíduo como negro.

Por outro lado, a inexistência entre nós de uma burguesia negra demostra que a questão racial e a questão social se fundiram. Por isso, Fabio Wanderley 
Reis (1996, p.231) considerou

[...] claramente odiosa, nas condições gerais que caracterizam as vastas camadas destituídas da população brasileira, a pretensão de se estabelecer discriminação entre as raças como critério para a ação de promoção social do Estado. Pondere-se que é justamente na base da pirâmide social, onde obviamente se encontram os alvos potenciais mais importantes do esforço social do Estado, que mais se mesclam e integram socialmente populações racialmente diversas, sem falar da ocorrência mais intensa da própria miscigenação.

Raciocínio semelhante encontramos no brasilianista George Reid Andrews (1996, p.138-9) ao lembrar, apoiando-se em dados, que a ação afirmativa, nos Estados Unidos, é uma política que "beneficiou principalmente, ou exclusivamente, a classe média negra; pouco ou nada fez para a classe pobre". Não surpreende, então, diz o autor,

[...] que o movimento negro nos anos 1980 tenha sido liderado em maior parte por membros dessa camada social; não surpreende também que alguns desses ativistas tenham reclamado a adoção de programas governamentais inspirados na experiência da ação afirmativa nos Estados Unidos. (ibidem, p.141)

Assim, foi preciso um intelectual americano, que nada tem de marxista, para lembrar o equívoco de buscar as referências para as nossas mazelas no exemplo norte-americano. Ele ainda teve a audácia de, num seminário aberto pelo presidente Fernando Henrique Cardoso, em pleno auge do neoliberalismo, lembrar aos presentes que o único programa governamental no mundo que reduziu as desigualdades raciais foi o cubano, que eliminou as diferenças raciais em saúde, expectativa de vida, educação e emprego. E isso só foi possível porque a ação governamental não se ateve à cor da pele, mas na promoção das camadas mais pobres da população.

A imposição da agenda racial levou Pierre Bourdieu e Loïc Wacquant a redigirem uma irada crítica à "exportação" das categorias oriundas no território norte-americano que, desistoricizadas, foram incorporadas pelos movimentos sociais e pelo mundo acadêmico. É o caso, entre outros, do multiculturalismo.

Referindo-se ao Brasil, eles perguntam:

[...] o que pensar desses pesquisadores americanos que vão ao Brasil encorajar os líderes do Movimento Negro a adotar as táticas do movimento afro-americano de defesa dos direitos civis e denunciar a categoria pardo (termo intermediário entre branco e preto que designa as pessoas de aparência física mista) a fim de mobilizar todos os brasileiros de ascendência africana a partir de uma oposição dicotômica entre "afro-brasileiros" e "brancos" no preciso momento em que nos Estados Unidos os indivíduos de origem mista se mobilizam a fim de que o Estado americano (a começar pelos Institutos de Recenseamento) reconheça, oficialmente, os americanos "mestiços", deixando de os classificar à força sob a etiqueta exclusiva de "negros"? (Bourdieu, 2002, p.23) 
Quanto ao mundo acadêmico, Bourdieu e Wacquant denunciam abertamente o imperialismo cultural:

[...] que desempenham as grandes fundações americanas de filantropia e pesquisa na difusão da doxa norte-americana no seio do campo universitário brasileiro, tanto no plano das representações como das práticas. Assim, a Fundação Rockefeller financia um programa sobre "Raça e Etnicidade" na Universidade Federal do Rio de Janeiro, bem como o Centro de Estudos Afro-Asiáticos (e sua revista Estudos Afro-Asiáticos) da Universidade Candido Mendes, de maneira a favorecer o intercâmbio de professores e estudantes. Para a obtenção de seu patrocínio, a Fundação impõe como condição que as equipes de pesquisa obedeçam aos critérios de affirmative actions à maneira americana, o que levanta problemas espinhosos já que, como se viu, a dicotomia branco/negro é de aplicação, no mínimo, arriscada na sociedade brasileira. (ibidem, p.22)

Um dos pontos centrais na "maneira americana" de tratar o problema é a postura crítica perante a nossa pretendida democracia racial. Tal democracia não é verdadeira, $\log$, caberia ao movimento negro denunciar a impostura e a hipocrisia.

Há, entretanto, outra maneira de enfrentar a questão, aquela sugerida pela melhor antropologia que entende a democracia racial brasileira como um mito. E um mito não é verdadeiro nem falso. Antes de tudo, ele é uma visão do mundo, um anseio coletivo, um princípio de integração social, um produto da consciência coletiva. O mito, portanto, é um relato, um sonho, que revela profundas aspirações sociais e valores latentes. Sendo assim, a mera denuncia é inócua, até porque uma das características do mito é a sua permanente autotransformação.

Lévi-Strauss (1970, p.252) afirmou ser o mito uma "filosofia nativa" que tem como objeto "fornecer um modelo lógico para resolver uma contradição". Numa interpretação livre, atenta à existência da contradição, pode-se aproximar essa tese antropológica da definição de Fernando Pessoa: "o mito é o nada que é tudo". Sem dúvida, o mito é um nada, pois indica um vazio, uma ausência; mas, o que é mais importante, projeta um futuro de reconciliação, uma nova totalização que acolhe e supera as diferenças. No caso que nos interessa: uma democracia a-racial em que a cor da pele dos indivíduos será finalmente uma característica insignificante.

\section{Lógica e política}

Lógica e política guardam entre si relações estreitas que convém explicitar.

A singularidade é velha companheira do anarquismo. Basta lembrar Stirner, autor de $O$ único e sua propriedade. A exaltação do indivíduo expulsa o particular e faz do universal uma coleção de indivíduos soltos e indiferenciados ou, como diria Hegel, uma "multidão atomística de indivíduos juntos". O jovem Marx, a propósito, observou que Stirner acreditava que esses indivíduos juntos mantivessem entre si relações puramente pessoais, isto é, relações não mediadas: descartava o particular ao desconsiderar que as relações pessoais se dão no interior das relações de classes. O particular, contudo, são as determinações sociais que se perdem na ênfase unilateral concedida à singularidade. 
Nos tempos atuais, assistimos ao florescimento do neoanarquismo presente nos movimentos sociais juvenis e no ciberativismo. ${ }^{10}$ Uma de suas manifestações teóricas mais elaboradas encontra-se na obra de Toni Negri (2003, p.43), especialmente em seu culto da multidão, definida por ele como "uma multiplicidade de singularidades que não pode encontrar unidade em nenhum sentido". A sociedade, como se percebe, surge aí como uma coleção de indivíduos soltos que recusam qualquer mediação, qualquer particular, que os represente na esfera política (sindicatos, partidos etc.).

A segunda categoria é a particularidade que a lógica tradicionalmente entende como uma mediação, que, ao superar o atomismo, pode permitir a via de acesso ao universal.

Mas pode também bloquear essa possibilidade. Há vários exemplos. Basta pensar no obreirismo, aquela concepção economicista que impede que a consciência operária supere o corporativismo e se transforme em consciência política. Ou, então, na famigerada "ética profissional", uma ética corporativa, particular, que existe independentemente da ética comum a todos os indivíduos.

As "ações afirmativas", com sua ênfase no particular, muitas vezes se chocam com os interesses universais. A inclusão social tem como objetivo a reparação de injustiças. Quando se procuram implementar políticas públicas reparadoras, surgem conselhos assim: entre dois candidatos igualmente qualificados que disputam um emprego, um negro e outro branco, a escolha deve recair sobre o primeiro. Com esse princípio ético, procura-se fazer justiça, mesmo quando o candidato branco é tão pobre, ou mais pobre, do que o negro. Essa justiça focada no particular, contudo, abre uma cisão no interior da sociedade, provoca uma reação contrária e acirra o preconceito. Estamos aqui diante de uma forma de inclusão social problemática centrada na "discriminação positiva" (ou, "discriminação ao inverso"), que reforça uma política separatista produtora de ressentimentos entre os não incluídos. A mesma coisa aplica-se às cotas na universidade, uma intervenção a meias que não soluciona a exclusão social, pois é apenas uma ação localizada, paliativa, uma forma de se fazer justiça a conta-gotas, num país em que 53\% dos habitantes se consideram negros e pardos.

Se a pequena política, como as expressas na afirmação de identidades e no culto às diferenças, permanece prisioneira do particular, a "grande política" poderia nos conduzir progressivamente ao universal. Trata-se aqui da ação política que induza os homens a superarem suas limitações singulares e a mera particularidade que os caracterizam para, assim, identificarem-se com o gênero humano.

No Estado democrático de direito, as políticas públicas deveriam caminhar nessa direção. No caso brasileiro, a superação da particularidade tem a seu favor o mito da "democracia racial", considerado por muitos apenas como uma "hipocrisia". Mas, a hipocrisia é uma homenagem que o vício presta à virtude. Há algo de importante e virtuoso nesse mito brasileiro que deveria servir de referência para construirmos uma democracia substantiva, sem adjetivações. 
1 Ecos dessa proposta estão presentes nos atuais movimentos das minorias: lembremos a parada do "orgulho gay" ou as camisetas que estampam frases como "orgulho de ser nordestino", "100\% negro" etc.

2 A partir daí, intensificaram-se estudos sobre as metamorfoses do olhar. Ver, por exemplo, Jay (1993). Uma análise bem informada sobre a trajetória do olhar foi feita por Fredric Jameson (2001). Jameson percorre os três momentos do olhar: em primeiro lugar, a introdução do tema na filosofia através de Sartre; o segundo momento é o da obra de Foucault, em que o olhar se liga diretamente à dominação (cujo símbolo maior é o Panóptico de Benthan); finalmente, o terceiro momento, o da pós-modernidade, é o da ditadura da imagem imposta pelo bombardeio midiático.

3 A psiquiatria, antigamente, considerava a histeria uma doença ligada à representação, e, não por acaso, atingindo predominantemente o sexo feminino. Nesse quadro patológico, a perda da autodeterminação atinge um ponto extremo que permite ver a dramaticidade teatral (representação) da luta inglória pelo autorreconhecimento através do outro.

4 O livro apresenta ainda um texto introdutório de Amy Gutmann e comentários de Susan Wolf, Steven Rockfeller e Michael Walzer, além de ensaios de Jürgen Habermas e K. Anthony Appiah.

5 Para um breve e competente roteiro, ver Costa e Werle (1997).

6 Esses autores têm sido estudados hoje como referências básicas para se entender a evolução do pensamento de R. Willams. Entre nós, destacam-se os trabalhos de Maria Elisa Cevasco (2001), André Glaser (2011) e Ugo Urbano Casares Rivetti (2015).

$7 \mathrm{O}$ "anseio de status das classes médias ameaçadas" revelou-se com todo o seu potencial explosivo no Brasil. Em 2015, o ressentimento contra as políticas de inclusão social e a não aceitação do veredicto das urnas, fizeram emergir o preconceito aberto (e não mais dissimulado) contra pretos, pobres e nordestinos. Paralelamente, as regras da convivência republicana (reconhecimento dos resultados eleitorais, respeito às decisões constitucionais etc.) foram postas de lado.

8 É o caso de Pierre Bourdieu (2002).

9 Os anais do seminários foram reunidos no livro Multiculturalismo e racismo: o papel da ação afirmativa nos Estados democráticos contemporâneos (Brasil, 1996).

10 Veja, a propósito, Celso Frederico (2013).

\section{Referências}

ANDREWS, G. R. Ação afirmativa: um modelo para o Brasil. In: BRASIL. Ministério da Justiça. Multiculturalismo e racismo: o papel da ação afirmativa nos Estados democráticos contemporâneos. Brasília: Ministério da Justiça. Secretaria Nacional de Direitos Humanos, 1996. p.138-9.

BEAUVOIR, S. de. O segundo sexo. São Paulo: Difusão Europeia do Livro, 1960.

BOURDIEU, P. Sobre as artimanhas da razão imperialista. Estudos Afro-Asiáticos, n.1, 2002. 
BRASIL. Ministério da Educação. Base Nacional Comum Curricular. Brasília: Ministério da Educação, s. d.

BRASIL. Ministério da Justiça. Multiculturalismo e racismo: o papel da ação afirmativa nos Estados democráticos contemporâneos. Brasília: Ministério da Justiça. Secretaria Nacional de Direitos Humanos, 1996.

CAHEN, M. Prefácio. Pode uma política de multiculturalidade existir sem uma grande narrativa?. In: MACAGNO, L. Dilemas do multiculturalismo. Curitiba: Graphia e Editora UFPR, 2014. p.19.

CEVASCO, M. L. Para ler Raymond Williams. Rio de Janeiro: Paz e Terra, 2001.

COSTA, S.; WERLE, D. L. Reconhecer as diferenças: liberais, comunitaristas e as relações raciais no Brasil. Novos Estudos, n.49, nov. 1997.

DESCOMBES, V. Lo mismo y lo outro. Cuarenta y cinco años de filosofia francesa (1933-1978). Madrid: Catedra, 1998.

FANON, F. Os condenados da terra. Juiz de Fora: UFJF, 2010.

FREDERICO, C. Da periferia ao centro: cultura e política em tempos pós-modernos. Estudos Avançados, São Paulo, n.79, 2013.

GLASER, A. Raymond Williams. Materialismo cultural. São Paulo: Biblioteca 24 Horas, 2011.

GRIN, M. Esse ainda obscuro objeto de desejo. Políticas de ação afirmativa e ajustes normativos: o seminário de Brasília. Novos Estudos, n.59, p.173, 2001.

HABERMAS, J. O Estado-Nação europeu frente aos desafios da globalização. Novos Estudos, n.43, p.94, 1995.

A inclusão do outro. Estudos de teoria política. São Paulo: Loyola, 2002.

JAMESON, F. Sobre os Estudos Culturais. Novos Estudos, n.39, p.29, jul. 1994.

Transformações da imagem na pós-modernidade. In: A cultura do dinheiro.

Rio de Janeiro: Petrópolis, 2001.

JAY, M. Downcast eyes: the denigration of vision in twentieth-century french thougth. Berkeley: s. n., 1993.

LÉVI-STRAUSS, C. Antropologia estrutural. Rio de Janeiro: Tempo Brasileiro, 1970.

MACAGNO, L. Dilemas do multiculturalismo. Curitiba: Graphia e Editora UFPR, 2014.

MEMMI, A. Portrait du colonisé précedé de portrait du colonisateur. Paris: Gallimard, 1985.

MONTERO, P. Multiculturalismo, identidades discursivas e espaço público. Sociologia \& Antropologia, n.02.04, p. 85-89, 2012.

NEGRI, T. 5 lições sobre o Império. Rio de Janeiro: DP\&A, 2003.

RAMOS, C. Do multiculturalismo como criação de novos targets: a política de identidades e a inscrição totalitária do gozo. A Peste, v.1, p.50 e 54, 2009.

REIS, F. W. Mito e valor da democracia racial. In: BRASIL. Ministério da Justiça. Multiculturalismo e racismo: o papel da ação afirmativa nos Estados democráticos contemporâneos. Brasília: Ministério da Justiça. Secretaria Nacional de Direitos Humanos, 1996. p.222. 
RIVETTI, U. U. C. Critica e modernidade em Raymond Williams. São Paulo: USP, 2015 (Mimeog.).

ROUANET, S. P. Universalismo concreto e diversidade cultural. In: VIEIRA, L. (Org.) Identidade e globalização. Rio de Janeiro: Record, 2009.

SARTRE, J.-P. Situações III. Lisboa: Publicações Europa América, 1971.

TAYLOR, C. El multiculturalismo y la "politica del reconoscimiento". Madrid: Fondo de Cultura Econômica, 2009.

ZIZEK, S. Multiculturalismo, o la lógica del capitalismo multinacional. In: JAMESON, F.; ZIZEK, S. Estudios culturales. Reflexiones del multiculturalismo. Buenos Aires: Paidós, 2008.

RESUMO - Após a Revolução Francesa de 1789 o Estado democrático estabeleceu os direitos universais do cidadão. Os movimentos sociais, inicialmente, encamparam esse ideal universalista e lutaram pelo reconhecimento de seus direitos: as mulheres obtiveram o direito de voto e os negros as leis antirracistas. Num segundo momento, o reconhecimento da igualdade cedeu lugar à luta pelo reconhecimento das diferenças. $\mathrm{O}$ texto procura enfocar as "ações afirmativas" implementadas pelo Estado e seus problemáticos resultados.

PALAVRAS-CHAVE: Multiculturalismo, Racismo; Ações afirmativas, Políticas públicas.

ABSTRACT - After the French Revolution of 1789, the democratic State established the universal rights of the citizen. Social movements initially embraced this universalist ideal and fought for the recognition of their rights: women gained the right to vote and blacks obtained anti-racist laws. Later, the recognition of equality gave way to the struggle for the recognition of differences. This text seeks to focus on "affirmative actions" implemented by the State and its problematic outcomes.

KErWORDs: Multiculturalism, Racism, Affirmative actions, Public policies.

Celso Frederico é professor da Escola de Comunicações e Artes da Universidade de São Paulo. @-celsof@usp.br

Recebido em 6.1.2016 e aceito em 16.2.2016.

${ }^{\mathrm{I}}$ Universidade de São Paulo, São Paulo/São Paulo, Brasil. 